\title{
„To be or not to be“: Cât de real este diagnosticul infecției COVID-19
}

\author{
Sorin Bivolaru ${ }^{1,2}$, Oana Cristina Voinea ${ }^{3}$, Manuela Arbune ${ }^{1,4}$ \\ ${ }^{1}$ Facultatea de Medicină și Farmacie, Universitatea „Dunărea de Jos“, Galaţi, România \\ ${ }^{2}$ Spitalul Militar de Urgenţă „Dr. Aristide Serfioti“, Galaţi, România \\ ${ }^{3}$ Centrul Medico-Militar de Cercetare Știinţifică, București, România \\ ${ }^{4}$ Spitalul Clinic de Boli Infecţioase „Sf. Cuv. Parascheva“, Galaţi, România
}

\begin{abstract}
REZUMAT
Pandemia COVID-19, determinată de noul coronavirus SARS-CoV-2, demonstrează variabilitatea evolutivă, atât din punct de vedere al severităţii, cât și al formelor de manifestare clinică. Prezentăm cazul unui pacient tânăr, fără comorbidităţi cronice, cu o infecţie respiratorie febrilă și modificări imagistice compatibile cu infecţia COVID-19, asociată cu manifestări dermatologice și neurologice. Testul RT-PCR SARS-CoV-2 a rămas negativ la două determinări succesive, dar testele serologice efectuate în convalescenţă au evidenţiat IgG anticoronavirus, indicând această etiologie. În concluzie, imagistica pulmonară, coroborată cu manifestările clinice și datele epidemiologice, poate susţine diagnosticul infecţiei COVID-19, deși confirmarea necesită RT-PCR SARS-CoV-2. Utilizarea testelor serologice pentru diagnostic, în cazurile cu suspiciune clinică ridicată și rezultate RT-PCR SARS-CoV-2 negative, permite creșterea ratei de identificare a infecţiilor acute, contribuind și la limitarea răspândirii infecţiei.
\end{abstract}

Cuvinte cheie: COVID-19, imagine de „sticlă mată“, erupţie maculo-papuloasă, RT-PCR SARS-CoV-2 fals negativ

\section{INTRODUCERE}

Infecţia COVID-19, determinată de noul coronavirus SARS-CoV-2, este caracterizată de rata foarte crescută de răspândire și de potenţialul de evoluţie severă, cu sindrom respirator acut sever, sepsis, tulburări de coagulare sau „furtună citokinică“, asociate cu mortalitate ridicată.

Din cauza variabilităţii manifestărilor clinice și a proporţiei crescute a cazurilor asimptomatice, definirea diagnosticului nu poate fi limitată la criteriile clinice (1). Diagnosticul COVID-19 se bazează pe istoricul epidemiologic, simptomatologie, modificări imagistice și se confirmă prin detectarea acidului nucleic viral (2).

Analiza riguroasă a fiecărui caz poate contribui la înţelegerea acestei infecţii emergente, care evoluează pandemic.

\section{PREZENTAREA CAZULUI}

Pacient în vârstă de 38 de ani, din mediul urban, nefumător, în antecedente cu multiple intervenţii operatorii pentru litiază renală bilaterală și cu alergii medicamentoase (aspirină, fasconal și nurofen), s-a prezentat în serviciul de urgenţă pentru febră, frisoane, dureri toracice şi tuse.

Boala a debutat în urmă cu 10 zile, cu artralgii ale articulaţiilor mari și dureri la nivelul inserţiei mușchilor mari ai membrelor, însoţite de dificultăţi la activităţi precum ridicarea în ortostatism sau urcatul scărilor și care s-au remis după 3 zile, utilizând doar aplicaţii locale cu antiinflamatorii. Debutul a mai fost însoţit de astenie fizică şi inapetenţă, care s-au accentuat progresiv. În ziua a patra de boală, au apărut leziuni eruptive rotund-ovalare, de dimensiuni variate, nepruriginoase, localizate la nivelul picioarelor, atât 
pe feţele dorsale, cât și plantare, cu caracter maculo-eritematos, neconfluent, aspect neomogen și care nu dispăreau la digito-presiune (Figura 1). Aceste leziuni au evoluat timp de 3 zile, ulterior au pălit și s-au remis complet.
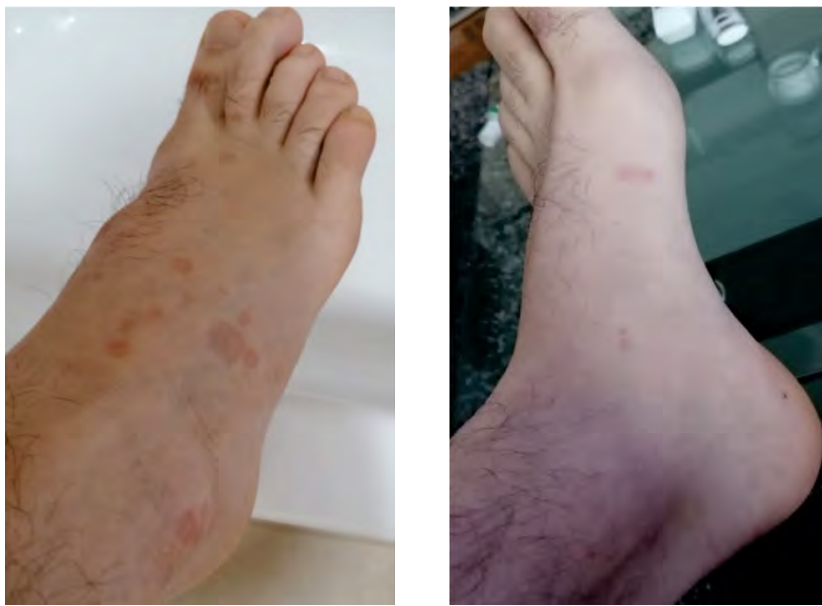

FIGURA 1. Leziuni maculo-papuloase asociate COVID-19

Începând din a 8-a zi de boală, starea generală s-a agravat, cu accentuarea asteniei, apariţia transpiraţiilor nocturne și a episoadelor subfebrile, însoţite de rinoree muco-purulentă cu striuri de sânge și tuse cu expectoraţie purulentă şi cheaguri de sânge, dar în cantitate redusă (Figura 2).

Febra a crescut până la $38,9^{\circ} \mathrm{C}$ din ziua a 9 -a de boală, cu frisoane, tuse accentuată, la care s-au asociat dureri toracice localizate precordial, tulburări de echilibru și parestezii ale membrelor inferioare.

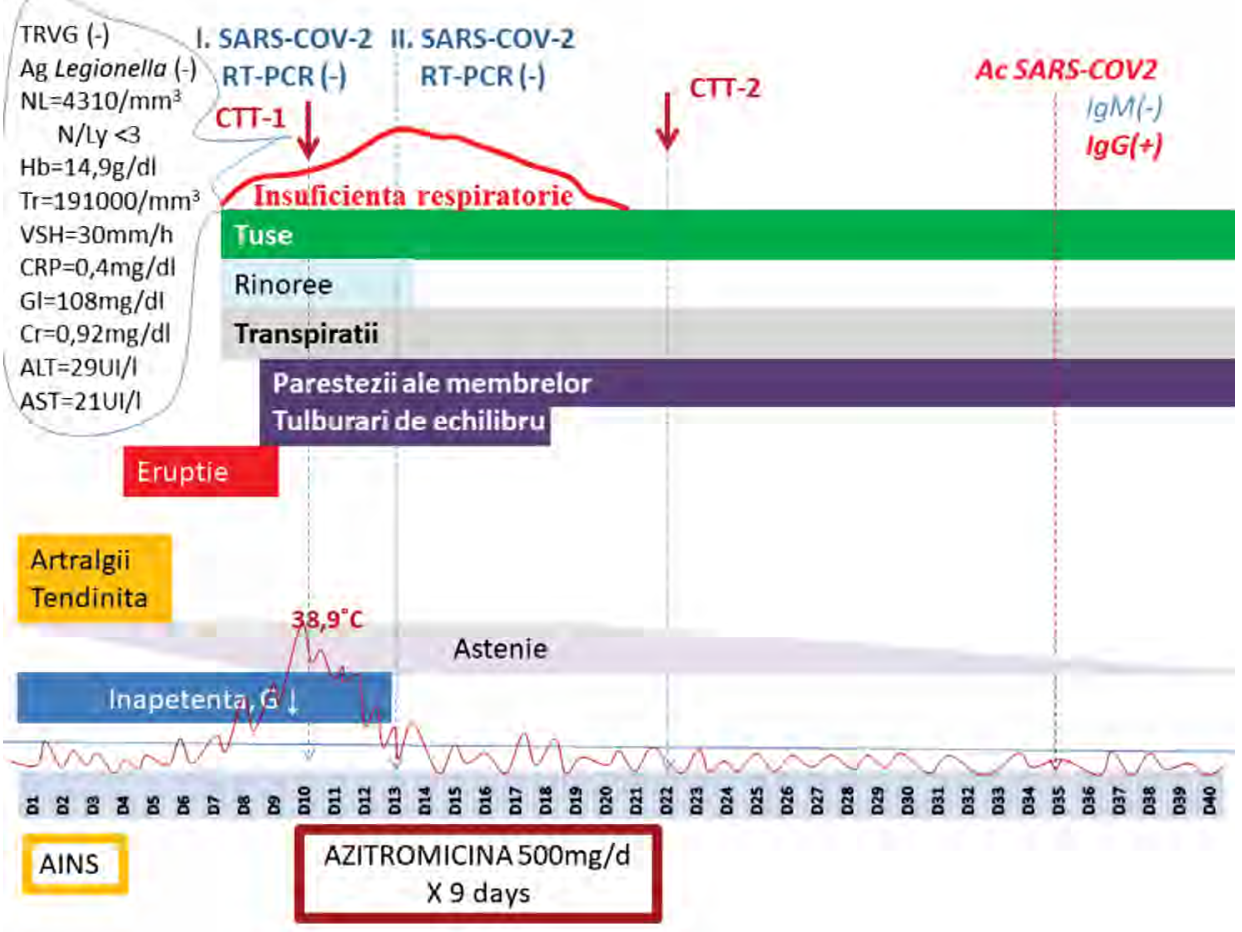

FIGURA 2. Evoluția infecției probabile COVID-19
Evaluarea medicală din a 10-a zi de boală, după administrarea la domiciliu de antitermice, a indicat stare generală moderat influenţată, cu scădere ponderală 5\% în ultima săptămână, stare de conştienţă normală, $\mathrm{T}^{\circ} 37,4^{\circ} \mathrm{C}$, TA $120 / 80 \mathrm{mmHg}$, FC 88/min, FR $24 / \mathrm{min}, \mathrm{SO}_{2} 97 \%$, auscultaţie pulmonară necaracteristică, tegumente intens transpirate, fără leziuni eruptive, fără semne meningiene sau semne de focar neurologic.

Datele clinice au sugerat diagnosticul de boală febrilă acută infecţioasă, luând în considerare cu prioritate afecţiuni respiratorii virale sau cu bacterii atipice, considerate pentru diagnosticul diferenţial.

Investigaţiile de laborator au avut valori normale, cu excepţia VSH moderat crescut.

Examenul computer-tomografic (CT) toracic a evidenţiat focare pulmonare cu aspect de, ,sticlă mată“ asociate cu leziuni alveolare, unele nodulare, localizate bazal bilateral, cu fină reacţie pleurală bazală bilaterală și periscizurită stângă (Figura 3). Examenul CT abdominal a fost normal, cu excepţia vizualizării unor microcalculi renali și a discretei hepato-splenomegalii difuze.

Testele rapide pentru virus gripal A/B și Ag urinar pentru Legionella spp. au fost negative.

În contextul evoluţiei epidemiei de COVID-19, deși ancheta epidemiologică nu a identificat legătura cu un caz suspect sau confirmat, s-a solicitat testul RT-PCR-SARS-CoV-2 din secreţiile nazo-faringiene, 

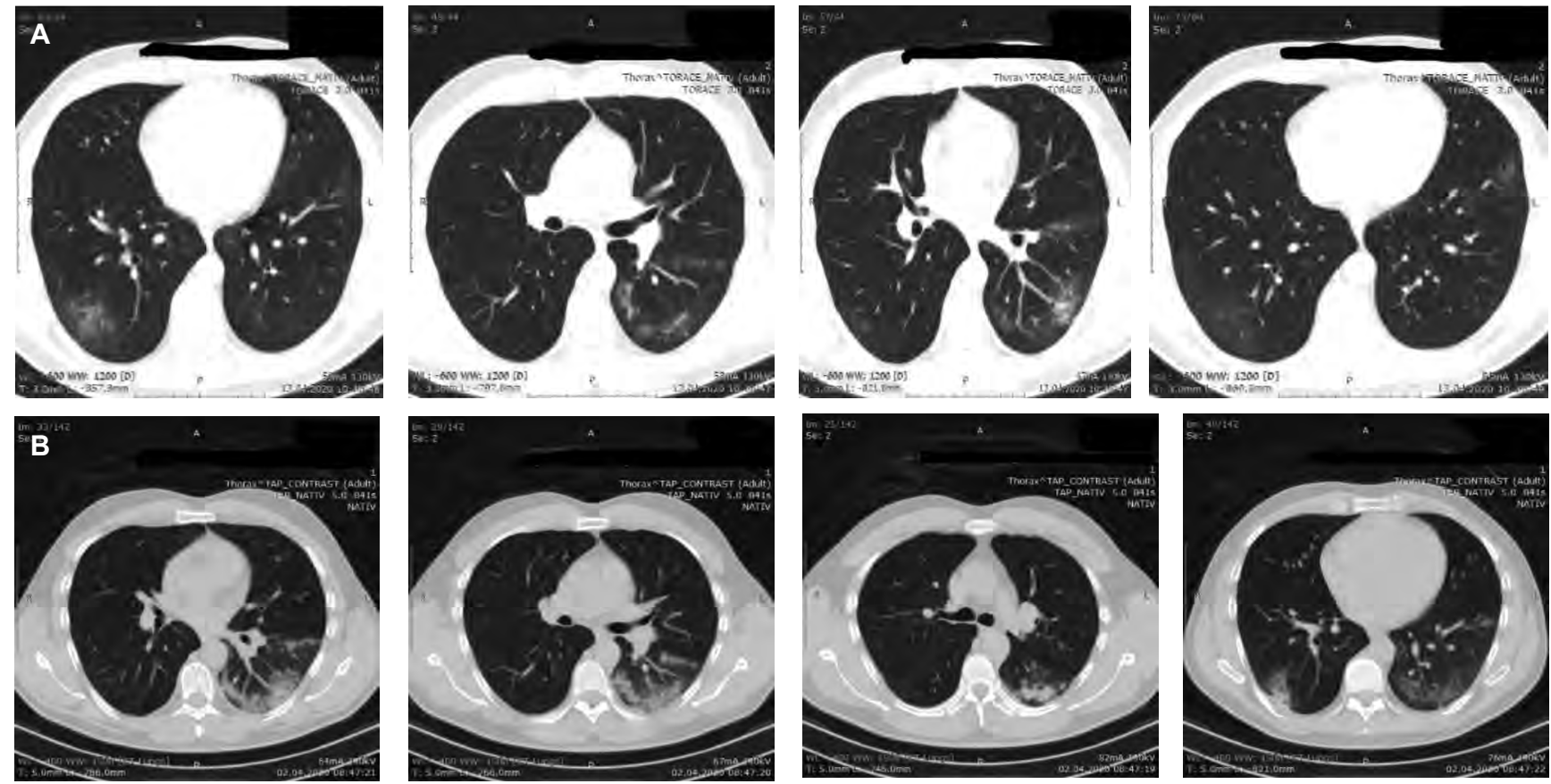

FIGURA 3. Computer tomografia toraco-pulmonară nativ $(A)$ şi cu substanță de contrast (B) - Focare cu aspect de „sticlă mată“ localizate difuz la nivelul lobului inferior stâng, asociate cu focare alveolare nodulare difuze, nesistematizate, predominant bazal posterior, subpleural; focar de „sticlă mată“ cu zonă nodulară de alveolizare adiacentă, localizată la nivelul lobului inferior drept segment bazal lateral, periferic; leziuni de periscizurită stângă; fină reactie lichidiană pleurală bilateral.

care a fost negativ. Totuşi, aspectul CT pulmonar a menţinut un grad ridicat de suspiciune pentru infecţia cu SARS-Cov-2 și a fost început tratamentul cu Azitromicină în ambulator.

După a 12-a zi de boală, deși febra era în scădere, au apărut episoade de dispnee, cu frecvenţă și intensitate în creștere, care au impus spitalizarea. La internare, s-a menţionat afebrilitatea, FR 28/min, $\mathrm{SO}_{2} 88 \%$ și FC 135/min, dar ECG nu a evidenţiat modificări semnificative, $\mathrm{cu}$ excepţia tahicardiei. Testul RT-PCR SARS-CoV-2 s-a repetat în a 13-a zi de boală, rezultatul fiind tot negativ. În această etapă, s-a stabilit diagnosticul: „Pneumonie bilaterală alveolară cu focare multiple și reacţie pleurală. Suspiciune clinică și imagistică de infecţie COVID-19, infirmată virusologic“.

Dupa externare, tratamentul cu Azitromicină 500 mg/zi a fost continuat până în ziua a 18 -a de boală, odată cu ameliorarea disfuncţiei respiratorii şi a toleranţei la efort.

Controlul CT efectuat după a 3-a săptămână de boală a evidenţiat ameliorarea imagistică, prin restrângerea cu $\sim 40 \%$ a opacităţilor descrise iniţial (Figura 3 ).

La reevaluarea realizată după 5 săptămâni de la debutul bolii, persistau uşoară tuse uscată, transpiraţii profuze, reci, predominant nocturne, și toleranţă la efort incomplet recuperată. Testul rapid pentru SARSCov-2 a evidenţiat Ac IgG pozitivi și Ac IgM negativi.

\section{DISCUṬII}

În acest caz, rămâne dilema: a fost sau nu a fost o infecţie COVID-19?

În contextul pandemiei COVID-19, sindromul febril, asociat cu disfuncţie respiratorie şi modificări imagistice de ,sticlă mată“, constituie fundamentul pentru o mare probabilitate de infecţie, dar care nu a fost confirmată virusologic.

Utilizarea unor teste care să identifice rapid şi cu acurateţe noul coronavirus SARS-CoV-2 este esenţială pentru diagnosticul precoce și controlul surselor de infecţie COVID-19. Testele serologice sunt importante pentru studiile epidemiologice și pentru evaluarea infecţiilor asimptomatice. Deși aceste teste nu sunt recomandate pentru diagnosticul bolii acute, un studiu recent a demonstrat prezenţa anticorpilor IgM și IgG după 5 zile de la debut, evidenţiindu-le utilitatea în cazurile cu rezultate fals negative la testele standard, din cauza recoltării inadecvate a secreţiilor respiratorii sau a tehnicii de testare inadecvate (3). Totuși, semnificaţia unor reacţii pozitive poate fi dubitabilă, luând în considerare posibilitatea unor reacţii încrucișate $\mathrm{cu}$ alte coronavirusuri respiratorii (4).

Metoda reacţiei de polimerizare in lanţ (PCR) este considerată „standardul de aur“ pentru diagnosticul de laborator al infecţiilor virale. Varianta „real-time“ 
(RT-PCR) este cea mai utilizată investigaţie pentru depistarea SARS-CoV-2, datorită simplităţii metodei, sensibilităţii şi specificităţii ridicate (5).

Rezultatele RT-PCR pot fi influenţate de diversitatea genetică şi de evoluţia rapidă a noului coronavirus, notificate de câteva studii (6).

Deși au fost dezvoltate mai multe tipuri de kituri pentru diagnosticul RT-PCR SARS-CoV-2, mutaţiile genomului viral explică rezultatele fals negative, prin nepotrivirile dintre secvenţele virale şi primerii complementari. În plus, dinamica încărcăturii virale este diferită de a altor coronavirusuri și variază de la un pacient la altul, dar și în funcţie de produsul biologic evaluat (3).

De aceea, un rezultat RT-PCR SARS-CoV-2, mai ales dacă sunt testate secreţiile respiratorii nazo-faringiene, nu exclude infecţia, dacă sunt prezente modificări imagistice caracteristice la examenul CT (7).

Imaginile CT cu aspect de ,sticlă mată““ au o mare valoare pentru diagnosticul infecţiei COVID-19, principalele caracteristici fiind distribuția periferică și subpleurală, afectarea multilobară, mai ales a lobilor inferiori, uneori asociate cu zone de consolidare focală. Totuși, leziunile de „sticlă mată“" nu sunt specifice, putând fi întâlnite și în alte afecţiuni, de exemplu în formele severe de gripă, în pneumoniile cu CMV, VSR, Mycoplasma pn., Chlamydia pn., Pneumocystis jiroveki (8).

Aspectul reticulat al pneumoniei COVID-19 se poate observa după 2 săptămâni de evoluţie, având potenţialul de fibroză ireversibilă, care necesită supraveghere pe termen lung (9).

Deși forma clinică a cazului este definită de afectarea principală pneumonică, evoluţia a prezentat particularităţi, prin asocierea sindromului eruptiv în prima săptămână de boală și a unui sindrom neurologic, manifestat cu tulburări de echilibru și parestezii ale membrelor, persistente după ameliorarea sindromului respirator.

Leziunile cutanate asociate COVID-19 au fost clasificate în cinci categorii: erupţii maculo-papuloase, urticariene, veziculoase, pseudo-degerături și livedo sau necroze. Acestea pot apărea rareori anterior debutului altor simptome ale infecţiei, de obicei concomitent manifestărilor clinice sau mai târziu, în cursul evoluţiei bolii. Într-o serie de 375 de cazuri cu erupţii asociate COVID-19, leziunile maculo-papuloase au fost identificate în $47 \%$ dintre cazuri, majoritatea au apărut concomitent cu alte simptome și s-au însoţit de evoluţie severă (10).

Antecedentele alergice în cazul pacientului prezentat și apariţia erupţiei înaintea manifestărilor respiratorii specifice au constituit dificultăţi de interpretare a diagnosticului dermatologic.

Tulburările neurologice asociate COVID-19 au fost menţionate de mai multe studii, mai ales în cazurile cu evoluţie severă. Cele mai frecvente manifestări sunt cefaleea şi ameţelile, raportate cu frecvenţă variabilă, între 3 și 12\%. Afectarea neurologică poate interesa atât sistemul nervos central, cât și sistemul nervos periferic, identificându-se două mecanisme patologice principale, prin leziuni hipoxice cerebrale sau prin leziuni mediate imunologic (11).

În plus, studii experimentale au evidenţiat potenţialul virusului de a pătrunde pe calea nervilor olfactivi direct la nivelul creierului, unde poate produce leziuni neuronale directe, prin legarea de receptorii ACE2 prezenţi la nivelul celulelor gliale și al neuronilor spinali (12).

\section{CONCLUZII}

Manifestările extrarespiratorii, raportate cu frecvenţă scăzută în cursul infecţiei COVID-19, pot contribui la dificultatea diagnosticului. Imagistica pulmonară, coroborată cu manifestările clinice și datele epidemiologice, poate susţine diagnosticul infecţiei COVID-19, deși confirmarea necesită RT-PCR SARS-CoV-2. Utilizarea testelor serologice pentru diagnostic, în cazurile cu suspiciune clinică ridicată şi rezultate RT-PCR SARS-CoV-2 negative, poate permite creșterea ratei de identificare a infecţiilor acute, contribuind și la limitarea răspândirii infecţiei.

\section{BIBLIOGRAFIE}

1. Tahamtan A, Ardebili A. Real-time RT-PCR in COVID-19 detection: Issues affecting the results. Expert Rev Mol Diagn. 2020;20(5):453454.

2. Corman VM et al. Detection of 2019 novel coronavirus (2019-nCoV) by real-time RT-PCR. Euro Surveill. 2020;25(3):2000045.

3. Loeffelholz MJ, Tang YW Laboratory diagnosis of emerging human coronavirus infections - the state of the art. Emerg Microbes Infect. 2020; 9(1):747-756.

4. Long $\mathrm{Q}$, Liu B, Deng $\mathrm{H}$ et al. Antibody responses to SARS-CoV-2 in patients with COVID-19. Nat Med, 2020. 
5. Shen M, Zhou Y, Ye J et al. Recent advances and perspectives of nucleic acid detection for coronavirus. J Pharm Anal. 2020.

6. Shen Z, Xiao Y, Kang L et al. Genomic diversity of SARS-CoV-2 in Coronavirus Disease 2019 patients. Clin Infect Dis. 2020:ciaa203 [ahead of print].

7. Wang $\mathrm{Y}$, Kang $\mathrm{H}$, Liu X, et al. Combination of RT-qPCR testing and clinical features for diagnosis of COVID-19 facilitates management of SARS-CoV-2 outbreak. J Med Virol. 2020 [ahead of print].

8. Wang Y, Dong C, Hu Y, Li C, Ren Q, Zhang X et al. Temporal changes of CT findings in 90 patients with COVID-19 pneumonia: A longitudinal study. Radiology, 2020.

9. $\mathrm{Hu} Q$, Guan $\mathrm{H}$, Sun $\mathrm{Z}$ et al. Early CT features and temporal lung changes in COVID-19 pneumonia in Wuhan, China. Eur J Radiol. 2020;128:109017 [ahead of print].
10. Galván Casas $C$, Català $A$, Carretero Hernández $G$ et al. Classification of the cutaneous manifestations of COVID-19: A rapid prospective nationwide consensus study in Spain with 375 cases. Br J Dermatol. 2020 [ahead of print].

11. Ahmad I, Rathore FA. Neurological manifestations and complications of COVID-19: A literature review. J Clin Neurosci. 2020.

12. Baig AM, Khaleeq A, Ali U, Syeda H. Evidence of the COVID-19 virus targeting the CNS: tissue distribution, host virus interaction, and proposed neurotropic mechanisms. ACS Chem Neurosci. 2020;11(7):995-998.

Conflict of interest: none declared Financial support: none declared 